\title{
Prevalence of Listeria monocytogenes in pork-meat and other processed products from the Colombian swine industry
}

\section{Prevalencia de Listeria monocytogenes en carnes y derivados de la industria porcícola colombiana}

\author{
Andrea Gamboa-Marín, ${ }^{1}$ M.Sc, Sonia Buitrago M, ${ }^{1}$ Microbiol, Karol Pérez-Pérez, ${ }^{1}$ Bact, \\ Marcela Mercado R, ${ }^{3}$ M.Epidemiol, Raúl Poutou-Piñales, ${ }^{2}$ Ph.D, \\ Ana Carrascal-Camacho, $1 *$ M.Sc
}

Pontificia Universidad Javeriana, Departamento de Microbiología. Facultad de Ciencias. ${ }^{1}$ Laboratorio de Microbiología de Alimentos. 2Laboratorio de Biotecnología Molecular. Grupo de Biotecnología Ambiental e Industrial (GBAI). ${ }^{3}$ Grupo de Enfermedades Infecciosas. Bogotá, D.C. Colombia. Correspondencia: acarrasc@javeriana.edu.co

Recibido: Octubre de 2011; Aceptado: Diciembre de 2011.

\begin{abstract}
Objective. To determine the prevalence of $L$. monocytogenes in pork carcasses, meat cuts, and meat products ("chorizo", sausage and ham). Materials and methods. Stratified sampling was implemented in meat-processed products. We analyzed $566(37 \%)$ carcasses, $472(31 \%)$ meat cuts, and 481, (32\%) meat-processed products, distributed as follows: 169 (11\%) sausage, 163 $(11 \%)$ ham, and $149(10 \%)$ "chorizo", for a total of $1519(100 \%)$ samples in a period of 18 months. The samples were processed using the ISO-17604, ISO-11290-1 and the USDA/FSIS (MLG-8.03) methods. Genus and species were confirmed by multiplex-PCR. Results. We obtained isolates of L. monocytogenes from 21 carcasses (10\%), 160 (76\%) from meat deboning, 10 (5\%) from ham, $6(3 \%)$ from "chorizo", and $13(6 \%)$ from sausage. The prevalence found was $3.7 \%$ and $33.9 \%$ in carcasses and meat deboning respectively. The prevalence in the meat-processed products was $4.03 \%$ in "chorizo", $6.13 \%$ in ham and $7.69 \%$ in sausage. The overall prevalence of $L$. monocytogenes in the study was $13.82 \%$. Conclusions. We found $L$. monocytogenes in different products analyzed, with particular interest in ham and sausage since both are consumed without previous heat treatment.
\end{abstract}

Key words: L. monocytogenes, porcine, pork-meat, prevalence (Source:DeCS y TDC).

\section{RESUMEN}

Objetivo. Determinar la prevalencia de L. monocytogenes en canales de cerdo, cortes de carne y derivados (chorizo, salchicha y jamón). Materiales y métodos. Se implementó un muestreo estratificado y se tomaron 566 muestras (37\%) de canales, 472 muestras (31\%) de cortes de carne y 481 muestras (32\%) de derivados cárnicos distribuidos de la siguiente manera: 169 (11\%) de salchicha, $163(11 \%)$ de jamón y $149(10 \%)$ de chorizo, para un total de $1519(100 \%)$ muestras en un período de 18 meses. Las muestras se procesaron utilizando las normas ISO-17604 e ISO-11290- 
1 y el método USDA/FSIS (MLG-8.03). Posteriormente se confirmaron los aislamientos por PCRmúltiple para identificar el género y la especie. Resultados. Se obtuvieron 21 (10\%) aislamientos de $L$. monocytogenes en muestras de canales, 160 (76\%) en carne de desposte, $10(5 \%)$ en jamón, $6(3 \%)$ en chorizo y $13(6 \%)$ en salchicha. La prevalencia encontrada fue de $3.7 \%$ y $33.9 \%$ en carne en canal y cortes de carne respectivamente, mientras que la prevalencia en los derivados fue chorizo $4.0 \%$, jamón $6.13 \%$ y salchicha $7.69 \%$. La prevalencia general de L. monocytogenes en el estudio fue $13.82 \%$. Conclusiones. Se encontró $L$. monocytogenes en los diferentes productos analizados, siendo de especial interés el jamón y las salchichas porque ambos son consumidos sin ningún tratamiento térmico.

Palabras clave: L. monocytogenes, porcino, carne de cerdo, prevalencia (Fuente:DeCS y TDC).

\section{INTRODUCTION}

L. monocytogenes is a Gram-positive non-spore forming bacilli that can be found individually, in pairs or as short chains of 3 to 5 microorganisms with a $\mathrm{V}$ or $\mathrm{Y}$ shape. It lacks a capsule and mobilizes by means of peritrichous flagella with an optimum mobilization temperature between 20 and $25^{\circ} \mathrm{C}$, with little or no mobility at $37^{\circ} \mathrm{C}(1)$. Although they are Gram-positive bacilli, old cultures can express pleomorphism. As a zoonotic and emerging microorganism in the food industry, $L$. monocytogenes causes listeriosis in humans and animals $(1,2)$. This ubiquitous bacterium can contaminate water, concentrates and especially farm silos, resulting in dissemination of $L$. monocytogenes during animal breeding. It is known for swines to excrete the bacteria thorugh their feces, thus acting as reservoirs (3).

L. monocytogenes has caused several food outbreaks, especially through a group of readyto-eat-food (REF), where meat- and dairyproducts are the most affected $(4,5)$. In several international reports pork galantine and ham, among other contaminated foods, has been declared as an important source of outbreaks in France and Canada $(1,6-8)$.

Presently in Colombia there are no outbreak reports by meat product consumption. However, a recent study conducted by the National Institute of Surveillance and Control of Beverages, Medicines and Food (INVIMA) stated that meat products may be contaminated with this microorganism and could constitute a potential listeriosis' vehicle (9). Recently, the INVIMA in its control and surveillance program reported the withdrawal of a batch of imported ham ("Serrano" type) due to the presence of $L$. monocytogenes. The Colombian legislation does not require searching for $L$. monocytogenes in meat derivates. However, the Institute of Technical Norms (Icontec), in its standard 1325 (sixth update), establishes the rejection of a product if 25 grams of the sample contain L. monocytogenes.
According to the national policy for safety and health regarding the pork chain (10), the Colombian porcine sector has experienced a significant growth with a considerable improvement in productivity. However, there are no reports determining the minimum permitted for this pathogen in the pork chain. One of the objectives stated in this work was to determine the prevalence of $L$. monocytogenes in meat derivatives, to help improve the porcine national chain health status. In Colombia prevalence reports of $L$. monocytogenes in meat derivates are scarce. This is most likely due to the fact that studies related with this microorganism have been focused on milk derivates. The few existing reports show prevalence of about $14.3 \%$ in meat derivates (11).

The main objective of this work was to determine the prevalence of $L$. monocytogenes in pork carcasses, pork-meat and pork-meat processed products from the domestic pork industry.

\section{MATERIALS AND METHODS}

Pork processing plant selection. Plants were selected according to the following criteria: 1 ) pork-only abbatoirs 2) plants that comply to regulations with Decree 1500 , i.e. pay a fee for development 3) plants located in areas determined by Fedegan (10). At the time of this study 42 processing plants were throughout the country, this study included 23.

Sample size. Sample size was calculated using the formula of timely estimate of prevalence, taking into account the following criteria. 1.) population size [1.927.273 slaughtered swines/ year], 2.) expected prevalence $[50 \%], 3$. expected maximum difference $[5 \%]$, 4.) error type I $[1 \%], 5$.$) sample size [566], 6$.$) number$ of plants for sampling [23]. 
Pork meat selection. As the inclusion criteria we considered: 1.) markets that sell pork and 2.) points located in the pork-industry areas. The number of samples to study was 472, distributed in 58 lots.

Selection of meat derivatives. For the selection of meat-processed products we took into account 1.) use of pork-meat as raw material and 2.) high consumption of pork-meat processed products. The products included were: cooked ham (sandwich type), low-cost sausage (cooked) and pre-cooked "chorizo". The number of included samples were 481, distributed as follows: 169 (35\%) sausages, 163 (34\%) ham, and 149 (31\%) "chorizo".

Sample collection. For pork carcasses, samples were collected using the nondestructive method described in standard ISO 17604 (12). Meat cuts were taken directly from market sale-points in different areas of the country, with a sample size of $500 \mathrm{~g}$. Meatprocessed products were taken directly from the sale point in commercial presentations with an approximate size of 250 to $500 \mathrm{~g}$.

Microbiological analysis. The samples were transported to the Laboratory of Food Microbiology at the Pontificia Universidad Javeriana, under aseptic conditions to be processed immediately. The method used for the processing of pork carcasses was described by the Department of Agriculture of United States (USDA/FSIS) (13). ISO11290-1 method was used for meat cuts and meat-processed products. Briefly, $25 \mathrm{~g}$ of sample was taken and homogenized in $225 \mathrm{ml}$ of Fraser-semi broth and incubated at $30^{\circ} \mathrm{C}$ for 48 hours. One hundred $\mu \mathrm{l}$ suspension was incubated in $10 \mathrm{ml}$ Fraser broth and incubated for 40 hours at $35^{\circ} \mathrm{C}$. $\mathrm{L}$. monocytogenes was isolated in Ottaviani-Agosti and Palcam agar. Presumptive colonies were purified in TSAYE agar. Catalase test, sugar fermentation (mannitol, Xylose, rhamnose), hemolysis test and Camp test were carried-out. Isolates that biochemically corresponded to $L$. monocytogenes were subjected to molecular identification (genus and species).

Master Cell Bank (MCB) development. A colony of each isolate was inoculated in $20 \mathrm{ml}$ of $\mathrm{BHI}$ broth, and incubated at $35^{\circ} \mathrm{C}$ for 24 hours at $120 \mathrm{rpm}$. The culture was then mixed at a proportion of $1: 1$ with glycerol at $40 \%(\mathrm{v} / \mathrm{v})$ and mixed thoroughly. One $\mathrm{ml}$ was placed in a cryopreservation vial, and stored at $-20^{\circ} \mathrm{C}$. Each MCB was periodically studied to verify the microbial purity and viability (14).
Genomic DNA extraction (gDNA). For genomic DNA extraction, a frozen vial of each isolate was inoculated in $5 \mathrm{ml} \mathrm{BHI}$ broth supplemented with $0.5 \%(\mathrm{p} / \mathrm{v})$ of glucose. Cells were cultured during 18 hours at $35^{\circ} \mathrm{C}$ and 120 $\mathrm{rpm}$. One $\mathrm{ml}$ culture was centrifuged during 10 minutes at $5000 \times \mathrm{g}$. Cells were washed with $1 \mathrm{XTE}$ buffer (10 mM Tris-HCl, $1 \mathrm{mM}$ EDTA, pH 8.0 \pm 0.2 ). DNA was extracted by using the "Wizard Genomic DNA Purification Kit" (Promega, Madison WI, USA).

Genomic DNA (gDNA) quantitation. DNA purity and concentration were determined (NanoDrop 2000c Thermo Scientific, Waltham, MA, USA) (15).

L. monocytogenes molecular identification by Multiplex-PCR. Primers used for the PCR reaction were L1 (CTCCATAAAGGTGACCCT)/U1(CAGCMGCCGCGGTAA TWC) and LF(CAAACGTTAACAACGCAGTA)/LR (TCCAGAGTGATCGATGTTAA) (16). The final volume of the reaction was $35 \mu \mathrm{l}$, containing $1 \mathrm{X}$ PCR buffer, $2.5 \mathrm{mM} \mathrm{MgCl} 2,0.2 \mathrm{mM}$ each dNTP, 20 pmol each primer and $2 \mathrm{U}$ of GoTaqFlexi DNApol (Promega, Madison WI, USA), and $5 \mu \mathrm{l}$ of gDNA ( $120 \mathrm{ng})$. Reactions were carried out in a Gene CyclerTM (BioRad, Philadelphia PA, USA) programmed in the following way: 1 minute at $950 \mathrm{C}$, followed by 40 cycles $\left(30 \mathrm{~s}\right.$ at $94^{\circ} \mathrm{C}, 20 \mathrm{~s}$ at $51^{\circ} \mathrm{C}, 30 \mathrm{~s}$ at $72^{\circ} \mathrm{C}$ ), and a final extension step of 8 minutes at $72^{\circ} \mathrm{C}$. L. monocytogenes ATCC 19115 was used as positive control (16).

Prevalence of $L$. monocytogenes. The following formula was used to calculate prevalence (17).

$$
\text { [1] Prevalence }(\%)=\frac{\text { Positive Samples }}{\text { Total Samples }} \times 100
$$

\section{RESULTS}

Molecular identification of $L$. monocytogenes by Multiplex-PCR. All the isolates previously identified as $L$. monocytogenes amplified the two expected products of $938 \mathrm{bp}$ and $750 \mathrm{bp}$, for genus and the species respectively (16). Figure 1 shows representational results.

Pork carcasses. Figure 2-top depicts outcomes for each of the analyzed processing plants. $L$. monocytogenes was isolated in $(8 / 23,34.8 \%)$ plants. Plant PB18 presented the greatest number of positive samples $(7 / 20,35 \%)$. $L$. monocytogenes was not isolated in other plants $(15 / 23,65.2 \%)$. The overall prevalence in pork carcasses was $3.7 \%(21 / 566)$. 


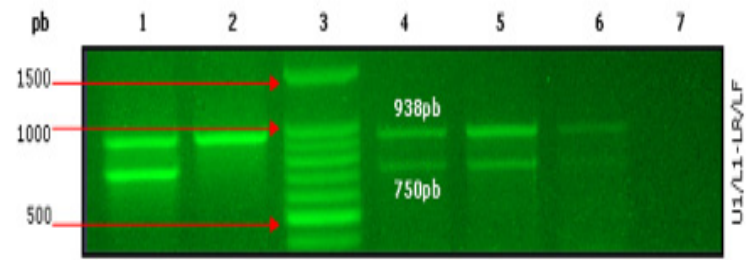

Figure 1. Molecular identification of $L$. monocytogenes. Representative samples of $L$. monocytogenes isolates in $1 \%(\mathrm{w} / \mathrm{v})$ TAE agarose gel processed in Quantity One V. 4.6.9. (BioRad, Philadelphia PA, USA). The figure shows some of the amplification products obtained by Multiplex-PCR. Lane $1: L$. monocytogenes ATCC 19115. Lane 2: Listeria spp. Lane 3: 100 bp molecular size marker (Promega, Madison WI, USA). Lanes 4, 5, 6: positive isolations for $L$. monocytogenes. Lane 7: Negative control for PCR reagents.

Meat cuts. Fifty eight lots of fresh pork meat were analyzed and $L$. monocytogenes was isolated in 40 lots (69\%). Out of the 40 lots thirteen samples were contaminated with $L$. monocytogenes $(22.4 \%)$. The bacterium was not isolated in the remaining $31 \%(18 / 58)$ of pork meat samples. There was an overall high prevalence (33.9\%, 160/472), (Figure 2-middle).

Pork meat processed products.

Ham. L. monocytogenes was isolated in 10 ham samples, with $6.13 \%$ prevalence (Figure 2-bottom).
Sausage. Out of 169 samples analyzed, $L$. monocytogenes was isolated in thirteen. The prevalence was $7.69 \%$ (Figure 2-bottom).

"Chorizo". Six isolates of L. monocytogenes were obtained for a prevalence of $4.03 \%$ (Figure 2-bottom).

\section{DISCUSSION}

L. monocytogenes is a food-transmitted pathogen with implications in the food industry due to its ubiquitous nature. This feature allows the bacterium to be disseminated in the environment, facilitating accession to meat-processing plants, in particular pork-meat processing product plants, favoring food contamination (18-20).

In the present study the prevalence of $L$. monocytogenes in meat carcassess was $3.7 \%$. These values are within the range of those published by other investigations: $2.0 \%$ in Finland (21), $4.1 \%$ in United States (22). Our results are lower than those presented by Gil and Jones who detected $8.3 \%$ in a Canadian plant. However, the Gil and Jones study only had 24 samples, which is not representative. Prevalence data from this research are consistent with several authors who have pointed out that processing plants are not a significant source of $L$. monocytogenes contamination. (23-27).
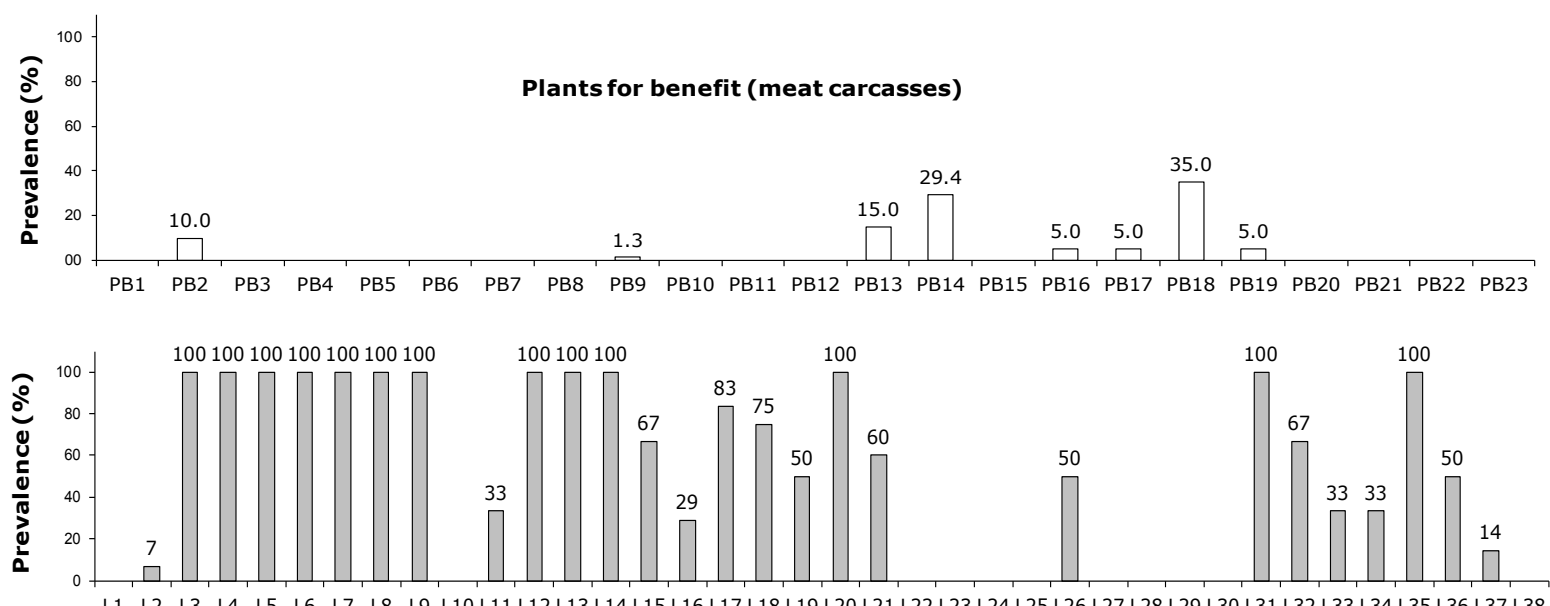

Deboning plants (Meat cuts)

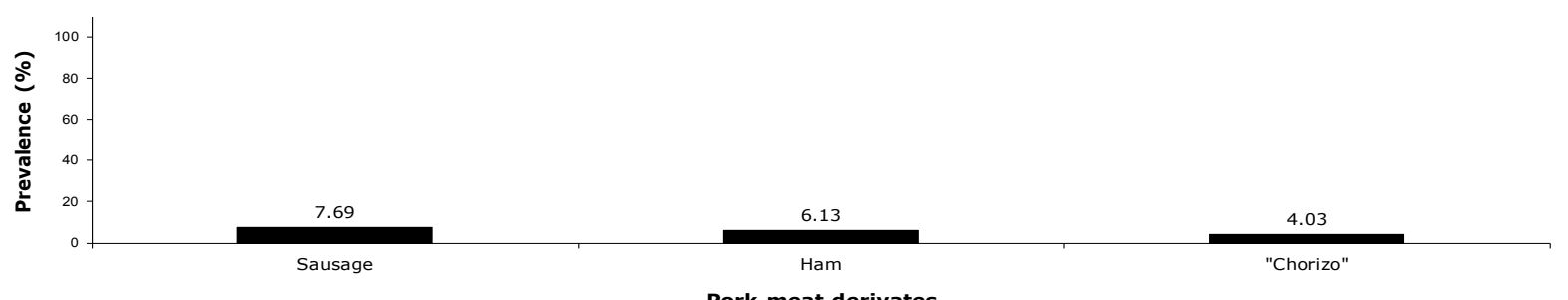

Pork meat derivates

Figure 2. Prevalence of $L$. monocytogenes in carcasses, meat cuts and meat products from the Colombian swine industry. 
The presence of the pathogen in swines is associated to the fact that these animals are carriers of $L$. monocytogenes. For example it has been shown that pork lodge this bacterium in tonsils and intestine $(3,21,22,28)$. For this reason if during evisceration there is organ rupture, the carcass can be contaminated with L. monocytogenes. Although it is frequent for L. monocytogenes to contaminate carcasses and processing plants, subsequent washing and disinfecting procedures should get rid of the contamination. Pathogen-free product depends on the effectiveness of these processes (21).

In this study meat cuts had a prevalence of $33.9 \%$. This percentage was the highest among all samples assayed. Our results agree with those reported by authors in different countries. Ochiai et al. reported an incidence of $35.7 \%$ in Tokyo (20). In contrast, other research shows lower prevalence and incidence: $0.15-1.2 \%$ in the United States (29), $4.0 \%$ in Finland (21), 5.0\% in Bulgaria (30), and $24.0 \%$ in Canada (8). The low prevalence in these countries can be associated to control measures implementation during the stages of cleaning and disinfection. It has been determined during deboning there might be cross-contamination with utensils. In particular if this process is carried out at room temperature below $10^{\circ} \mathrm{C}$. This favors the presence of $L$. monocytogenes due to its psychrotrophic nature $(20,28)$. The conditions of contact surfaces and equipment affect the persistence of $L$. monocytogenes. Stainless steel surfaces are used in the food industry to prevent contamination (26).

In the present study prevalence of $L$. monocytogenes in sausage was $7.69 \%$, similar to that found by Vera et al (11) in Bogotá in 2004 (document published in 2006). Vera et al (11) reported a prevalence of $8.7 \%$ with 21 positive samples of 239 evaluated sausages. Similar findings were reported by Karakolev et al (30) in 2009. They analyzed and determined prevalence in crude dried sausage $(11.3 \%)$ and raw smoked sausage (8.6\%) in Bulgaria (30). Other investigations have presented prevalence of $42.0 \%(31), 28.2 \%$ in fresh and fermented sausages (32), and $16.9 \%$ in dry cured sausage (33). These studies show that there is variability in the prevalence of $L$. monocytogenes in sausage, which may be related to preparation process and storage (29). It is noteworthy that $L$. monocytogenes' prevalence is dependent on the country and the nature of the product-processing. As a case in point, raw fermented sausage or products without proper packaging can have a higher prevalence. In contrast, the samples evaluated in this study were sausages cooked and vacuum packed at the production plant.
Sausages are regional products that vary depending on the country with regards to ingredients and production processes. In some cases they are considered a type of fermented sausage, making it difficult to compare porkmeat processed products from different origins, in particular with the international literature.

The prevalence of $L$. monocytogenes in "chorizo" was $4.0 \%$, less than what was stated by Vera et al (11). They reported in Bogotá (2004) a prevalence of $18.1 \%$ with two positive samples out of 11 assessed. Their results might be due to a low sampling number and sampling of precooked sausage.

In the case of the ham the prevalence in the present research was $6.13 \%$. This prevalence was higher than what was reported by Martins and Leal $(0.8 \%)(20)$, but lower than that reported by Cabedo et al (33) (12.5\%). Vera et al (11) also reported higher prevalence $(16.8 \%)$ with 67 positive samples out of 398 analyzed. Ham contamination may occur during slicing and/or packaging probably due to the presence of the pathogen in equipment, when hygiene conditions are not appropriate $(20,26)$.

Chasseignaux et al. pointed-out to contamination of meat products with $L$. monocytogenes associated to cross-contamination with raw meat, equipment, processing areas (34), cooling areas, or even staff of the establishment. Therefore the incorporation of the microorganism in REF occurs after having subjected the product to thermal processes.

Lastly, it is important to note that $L$. monocytogenes was found in different samples analyzed. This demonstrates the importance of pork meat products as a transmission vehicle for this bacterium.

\section{Acknowledgments}

This work was supported by grants from the Ministry of Agriculture and Rural Development (Isolation and molecular characterization of strains of Salmonella spp., and L. monocytogenes antimicrobial susceptibility and valuation of the microbiological risk of contamination in meat in carcasses, pork meat cuts, strategies for prevention and control in plants and processing registration code 2008 W4845), and Pontificia Universidad Javeriana, Bogotá, D.C., Colombia (00003120). The authors also like to thank Maria Lucia Gutiérrez for English editing the manuscript. 


\section{REFERENCES}

1. Torres KJ, Sierra SC, Poutou RA, Vera $H$, Carrascal AK, Mercado M. Incidencia y diagnóstico de Listeria monocytogenes; microorganismo zoonótico emergente en la industria de alimentos. Rev UDCA Act Divulg Cient 2004; 7(1):25-57.

2. Torres KJ, Sierra SC, Poutou RA, Carrascal AK, Mercado M. Patogénesis de Listeria monocytogenes, microorganismo zoonótico emergente. Rev MVZ Córdoba 2005; 10(1):511-543.

3. Belalcazar ME, Poutou RA, Torres $\mathrm{KJ}$, Gallegos JM, Torres O, Carrascal AK. Listeria monocytogenes y listeriosis animal. Rev UDCA Act Inv Cient 2005; 8(2):95-101.

4. Fox EM, Leonard N, Jordan K. Molecular diversity of Listeria monocytogenes isolated from Irish dairy farms. FPD 2011; 8(5):635-641.

5. Vanegas MC, Vasquez E, Martinez AJ, Rueda AM. Detection of Listeria monocytogenes in raw whole milk for human consumption in Colombia by real-time PCR. Food Cont 2009; 20:430-432.

6. Vaillant $\mathrm{V}$, De Valk $\mathrm{H}$, Baron $\mathrm{E}$, Ancelle $\mathrm{T}$, Colin P, Delmas B et al. Foodborne infections in France. FPD 2005; 2(3):221-232.

7. Taillefer $C$, Boucher $M$, Laferrière $C$, Morin L. Perinatal listeriosis: Canada's 2008 Outbreaks. J Obst Gynaec Canada 2010; 32(1):45-48.

8. Bohaychuk VM, Gensler GE, King RK, Manninen KI, Sorensen O, Wu JT et al. Occurrence of pathogens in raw and ready-to-eat meat and poultry products collected from the retail marketplace in Edmonton, Alberta, Canada. J Food Prot 2006; 69(9):2176-2182.

9. Muñoz AI, Vargas $M$, Otero $L$, Díaz G, Guzmán V. Presencia de Listeria monocytogenes en alimentos listos para el consumo, procedentes de plazas de mercado y delicatessen de supermercados de cadena en Bogotá D.C, 2002-2008. Biomédica 2011; 31(3):428-439.
10. Consejo Nacional de Política Económica y Social (Conpes 3458). Política nacional de sanidad e inocuidad para la cadena porcícola In. Bogotá. D.C. Colombia: Ministerio de Agricultura y Desarrollo Rural, Ministerio de Protección Social, Ministerio de Ambiente, Vivienda y Desarrollo Territorial, Ministerio de Comercio, Industria y Turismo; 2007.

11. Vera $\mathrm{H}$, Ferro CJ, Triana LM. Prevalencia de Listeria moncytogenes en derivados cárnicos cocidos para consumo directo analizados en el laboratorio de salud pública, Bogotá 1 de septiembre 200131 agosto de 2004. In. Bogotá, D.C., Colombia: Laboratorio de Salud Pública, Secretaría Distrital de Salud, Bogotá, D.C., Colombia; 2006.

12. ISO. International Standardizartion Organization: Microbiology of food and animal feeding stuffs-carcass sampling for microbiological analysis (ISO17604) 2003.

13. USDA-FSIS. Isolation and Identification of Listeria monocytogenes from Red Meat, Poultry, Egg and Environmental Samples. MLG 8.07. In: USDA/FSIS Microbiology Laboratory Guidebook. Washington, D.C.: United States Department of Agriculture. Food Safety and Inspection Service; 2002.

14. Meza RA, Monroy AF, Mercado M, Poutou RA, Rodríguez P, Pedroza AM. Study of the stability in real time of cryopreserved strain banks. Univ Sci 2004; 9(2):35-42.

15. Sambrook J, Russell DW. Molecular cloning: A laboratory manual, vol. 3, 3th Edition edn. Appendices. New York: Cold Spring Harbor Laboratory Press; 2001.

16. Ruiz-Bolivar Z, Carrascal-Camacho AK, Neuque-Rico MC, Gutiérrez-Triviño C, Rodríguez-Bocanegra MX, Poutou-Piñales RA et al. Enterobacterial Repetitive Intergenic Consensus-Polymerase Chain Reaction (ERIC-PCR) fingerprinting reveals intra-serotype variations among circulating Listeria monocytogenes strains. Afr J Microbiol Res 2011; 5(13):1586-1598. 
17. Hernández-Chavarría F. Fundamentos de epidemiología: el arte detectivesco de la investigación epidemiológica. Costa Rica: EUNED; 2002.

18. Molero G, Tarradas C, Ramírez I, Gallardo F, Montiel M. Aislamiento e identificación de Listeria monocytogenes durante el proceso de beneficio de pollos en plantas beneficiadoras en el estado Zulia, Venezuela. Ciencia 2010; 18(2):108-114.

19. Martins EA, Leal Germano PM. Listeria monocytogenes in ready-to-eat, sliced, cooked ham and salami products, marketed in the city of São Paulo, Brazil: Occurrence, quantification, and serotyping. Food Cont 2011; 22(2):297-302.

20. Ochiai Y, Yamada F, Batmunkh O, Mochizuki M, Takano T, Hondo R et al. Prevalence of Listeria monocytogenes in retailed meat in the Tokyo metropolitan area. J Food Prot 2010; 73(9):1688-1693.

21. Hellstrom S, Laukkanen R, Siekkinen KM, Ranta J, Maijala R, Korkeala H. Listeria monocytogenes contamination in pork can originate from farms. J Food Prot 2010; 73(4):641-648.

22. Kanuganti SR, Wesley IV, Reddy PG, McKean J, Hurd HS. Detection of Listeria monocytogenes in Pigs and Pork. J Food Prot 2002; 65(9):1470-1474.

23. Nightingale KK, Fortes ED, Ho AJ, Schukken $\mathrm{YH}$, Grohn YT, Wiedmann M. Evaluation of farm management practices as risk factors for clinical listeriosis and fecal shedding of Listeria monocytogenes in ruminants. J Amer Vet Med Associat 2005; 227(11): 1808-1811.

24. Peccio A, Autio $T$, Korkeala $H$, Rosmini $\mathrm{R}$, Trevisani M. Listeria monocytogenes occurrence and characterization in meatproducing plants. Lett Appl Microbiol 2003; 37(3):234-238.

25. Jessen B, Lammert L. Biofilm and disinfection in meat processing plants. Int Biodet Biod 2003; 51(4):265-269.

26. Chasseignaux $E$, Gérault $P$, Toquin $M T$, Salvat G, Colin P, Ermel G. Ecology of Listeria monocytogenes in the Environment of Raw Poultry Meat and Raw Pork Meat Processing Plants. FEMS Microbiol Let 2002; 210:271-275.
27. Lundén JM, Autio TJ, Korkeala HJ. Transfer of persistent Listeria monocytogenes contamination between food processing plants associated with a dicing machine. J Food Prot 2002; 7:1129-1133.

28. Thévenot D, Dernburg A, VernozyRozand C. An updated review of Listeria monocytogenes in the pork meat industry and its products. J Appl Microbiol 2006; $101: 7-17$.

29. Wesley IV, Larsen S, Hurd HS, McKean JD, Griffith R, Rivera F et al. Low prevalence of Listeria monocytogenes in cull sows and pork. J Food Prot 2008; 71(3):545-549.

30. Karakolev R. Incidence of Listeria monocytogenes in beef, pork, raw-dried and raw-smoked sausages in Bulgaria. Food Cont 2009; 20:953-955.

31. Miyasaki KN, Chiarini E, Sant Ana AD, Destro MT, Landgraf M, Franco BD. High prevalence, low counts and uncommon serotypes of Listeria monocytogenes in linguica, a Brazilian fresh pork sausage. Meat Sci 2009; 83:523-527.

32. De Cesare A, Mioni R, Manfreda G. Prevalence of Listeria monocytogenes in fresh and fermented Italian sausages and ribotyping of contaminating strains. Int J Food Microbiol 2007; 120(1-2):124-130.

33. Cabedo L, Picart i Barrot $L$, Teixido i Canelles A. Prevalence of Listeria monocytogenes and Salmonella in readyto-eat food in Catalonia, Spain. J Food Prot 2008; 71(4):855-859.

34. Chasseignaux E, Toquin MT, Ragimbeau C, Salvat G, Colin P, Ermel G. Molecular epidemiology of Listeria monocytogenes isolates collected from the environment, raw meat and raw products in two poultry and pork processing plants. J Appl Microbiol 2001; 91(5):888-899. 